\title{
The Prevalence of Tonsillar Human Papilloma Virus Infection in İstanbul, Turkey: A Human Cadaver Study
}

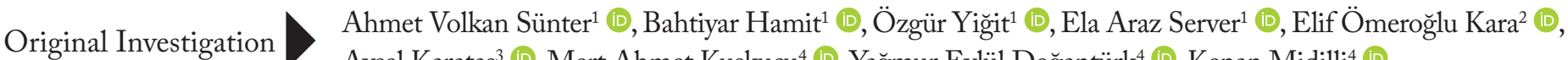 \\ Aysel Karataş3 (D), Mert Ahmet Kuşkucu+ (D), Yağmur Eylül Doğantürk ${ }^{4}$ (D), Kenan Midillii (D) \\ ${ }^{1}$ Department of Otorhinolaryngology/Head and Neck Surgery, İstanbul Training and Research Hospital, İstanbul, Turkey \\ ${ }^{2}$ Department of Forensic Medicine, Ministry of Justice, İstanbul, Turkey \\ ${ }^{3}$ Department of Medical Microbiology, İstanbul Training and Research Hospital, İstanbul, Turkey \\ ${ }^{4}$ Department of Medical Microbiology, İstanbul University-Cerrahpaşa, Cerrahpaşa School of Medicine, İstanbul, Turkey
}

Abstract

ORCID IDs of the authors:

A.V.S. 0000-0001-8601-0450;

B.H. 0000-0002-2516-7670;

Ö.Y. 0000-0003-1731-3233;

E.A.S. 0000-0002-8462-3605;

E.0.K. 0000-0001-7548-7261;

A.K. 0000-0001-8916-8499;

M.A.K. 0000-0001-8735-5725;

Y.E.D. 0000-0001-5034-2058;

K.M. 0000-0003-3007-3422.

Cite this article as: Sünter AV, Hamit B, Yiğit Ö, Araz Server E, Ömeroğlu Kara E, Karataş A, et al. The Prevalence of Tonsillar Human Papilloma Virus Infection in istanbul, Turkey: A Human Cadaver Study. Turk Arch Otorhinolaryngol 2019; 57(3): 117-21.

\section{This study was presented at the $39^{\text {th }}$ Turkish} National Otolaryngology Head and Neck Surgery Congress 8-12 November, 2017, Antalya, Turkey.

\section{Corresponding Author:}

Ahmet Volkan Sünter; avsunter@gmail.com

Received Date: 8.03.2019

Accepted Date: 02.08 .2019

Content of this journal is licensed under a Creative Commons Attribution 4.0 International License.

Available online at www.turkarchotolaryngol.net
Objective: To investigate the prevalence of tonsillar human papillomavirus infection in İstanbul, the most populous city of Turkey.

Methods: Tonsil specimens were obtained from 206 cadavers aged 18 to 89 years. Tonsillectomy was performed during routine autopsy for each subject in the 24 hours after death. After dissolution, tissues were processed with the polymerase chain reaction (PCR) method to identify HPV DNA. The data obtained from the DNA sequencer were processed in the database of GenBank ${ }^{\circledR}$.
Results: One hundred sixty-six (80.6\%) male and 40 (19.4\%) female cadavers were included in the study. One case demonstrated HPV-16, one had HPV-82, one had HPV-55 and one had HPV-13. All four cases were male. Prevalence of tonsillar HPV was $1.94 \%$ and of HPV 16 was $0.48 \%$.

Conclusion: The prevalence of tonsillar HPV infection was found $1.94 \%$ and of HPV $160.48 \%$ in our study.

Keywords: Human papilloma virus, HPV, oropharynx, palatine tonsil

\section{Introduction}

Smoking and alcohol consumption are the major risk factors for squamous cell carcinoma, the most common histologic type of head and neck cancers (1). Although the incidence of smoking-related head and neck cancers decreased with anti-smoking campaigns, the frequency of oropharyngeal cancers increased $(2,3)$. Oropharyngeal cancers are most commonly seen in the tonsils. Recently, Human Papilloma Virus (HPV) is observed to be closely related to the oropharyngeal carcinogenesis, hence emerged as a new etiological factor. Studies show that HPV-16, which is a high-risk carcinogen subtype of HPV, is detected in more than half of the specimens of oropharyngeal cancers (4-6). A study conducted in Turkey in the years 19962003 found the prevalence of HPV in oropharyngeal cancer patients to be $38.4 \%$ (7). In the same study, the prevalence of HPV in oropharyngeal cancers was found to be $62.7 \%$ between 2004-2011.
Human Papilloma Virus is a DNA virus that contains small, double-stranded and circular genome. More than 200 identified subtypes of the virus are divided into two groups as low-risk, and high-risk (8). HPV-16 and HPV-18 are the most commonly observed types of the high-risk group.

In the first stage of HPV-related carcinogenesis, the genome of the virus is integrated into the chromosomes of the target tissue. The integrated virus initiates the oncogenic process by leading to over-expression of E6 and E7 and suppressing $\mathrm{Rb}$, and $\mathrm{p} 53$ (8). Anogenital cancers are the most commonly seen type among HPV-related cancers, and cervix cancers constitute the significant subgroup. HPV-specific molecular tests are widely used in the detection process of HPV in precancerous lesions of the cervix. These tests facilitate the early detection and the treatment of the cervix cancer (9). This improvement, however, hasn't been achieved for oropharyngeal 
cancers yet. Screening of HPV infection for oropharyngeal cancer is as significant as for genital cancer.

There are many studies on the prevalence of HPV infection. Methods and sites of specimen collection vary among these studies. Most commonly preferred methods for the identification of viral DNA include sampling by oral rinse or mouthwash, buccal mucosa swabbing, sampling of saliva, and tonsillectomy. Oral rinse and saliva sampling both provide the sampling of the oral cavity and the oropharynx at the same time, an approach that could be a disadvantage in identifying the exact localization of the infection (10). Sampling from the buccal mucosa are mainly used for detecting the infection in the oral cavity. Therefore, sampling from the tonsillar tissue is the best method for detecting HPV-related oropharyngeal (or tonsillar) carcinoma. In most of the studies on the prevalence of HPV infections, tonsillectomy specimens were used (11). Its prevalence among the patients who undergo tonsillectomy due to recurrent/chronic tonsillitis or tonsillar hypertrophy could be unsatisfactory when the whole population is considered. In our study, we aimed to investigate the prevalence of HPV in the broader population by obtaining the tonsillar tissue of the cadavers during routine autopsies. To the best of our knowledge, this is the only study, which aims to explore the prevalence of HPV in the tonsillar tissue among the Turkish population.

\section{Methods}

Ethics committee approval was obtained from the Department of Forensic Medicine Institution, Education and Scientific Research Commission (06.08.2015-21589507/704). The study included morphologically normal 206 tonsillar tissues, which were obtained from cadavers over 18 years of age. Palatine tonsil samples were collected from the Forensic Medicine Institution from January 2016 to May 2016. Any cadavers with unknown time of death, or death by burning, choking, hanging, penetrating neck traumas, or those who were pre-mortally intubated, and foreign nationalities were all excluded. Age, gender and the cause of death of all cadavers were noted. The duration between the time of the death and the autopsies were no longer than 24 hours. Due to the inadequate exposition of the oropharynx in the cadavers, tonsillectomies were performed by transcervical cold dissection method via neck incision, which is routinely performed during autopsy after the examination of the neck structures. After routine dissection of the larynx, the tongue and the tongue base from the prevertebral fascia, tonsils were removed by the transcervical method and kept under $-80^{\circ} \mathrm{C}$ in sterile containers.

\section{Nucleic acid purification and genotyping of the samples}

Tonsillar tissues, which were kept under $-80^{\circ} \mathrm{C}$ and viral transport conditions, were dissolved. Sampling and defragmentation were done using lancets, and thereby preliminary homogenization was achieved. The fragmented tissue was transferred to the screw cap tube. $250 \mu \mathrm{l} 1 \mathrm{X}$ polymerase chain reaction (PCR) buffer and $50 \mu 1$ proteinase $\mathrm{K}$ were added to the tube and the mixture was vortexed. Then the mixture was incubated in the heating block for two hours for preliminary lysis. Nucleic acid samples were obtained from these homogenized mixtures by using the Quiagen EZ1 Virus Mini Kit (Quiagen, Germany). The instructions of the manufacturer were followed in this process. HPV DNA analysis was achieved by using primers My09-11 and Gp05-06 (Invitrogen, Germany) via nested PCR. In the first stage, My0911 primers were used. Nucleic acid samples were processed through PCR by using human beta-actin primers. Thereby, the possibility of the presence of any PCR inhibitors in the samples and following false negative results were excluded. In the second stage, GP05-06 primers were used for PCR. PCR products were processed in 1.5\% agarose gel electrophoresis for the control and evaluation stage (Midicell Primo, Thermo Scientific, USA). Bands were observed in the gel imaging system (Biorad, Germany) and positive band images in 200 bp were recorded. These PCR products were kept under $-20^{\circ} \mathrm{C}$ to be processed with bi-directional sequence analysis.

Polymerase chain reaction products that were positive for DNA sequence analysis were purified using a Gene Matrix Basic DNA Purification Kit according to the instructions of the manufacturer. Sequencing was processed bi-directionally using the DyeTerminator method (BigDye Terminator v3.1 Kit Applied Biosystems, Foster City, USA). The data collected from the genetic analysis device were edited and bi-directionally sequenced. These sequences were integrated into the GenBank $^{\circledR}$ and the most overlapped types were detected for each sample.

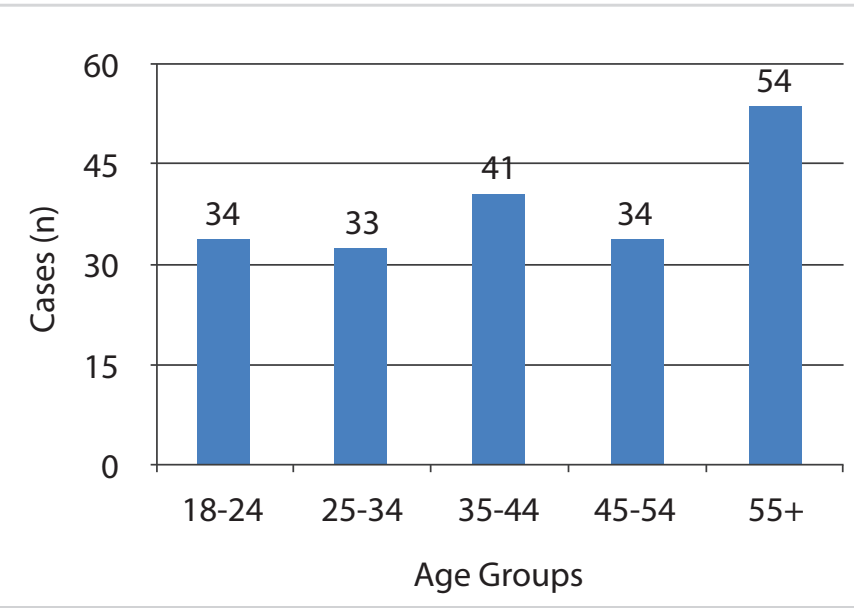

Figure 1 . Number of cadavers by age groups

Table 1. HPV positive cases

\begin{tabular}{l|c|c|c}
\hline & Age & Sex & HPV Type \\
\hline Case 1 & 20 & Male & 13 \\
\hline Case 2 & 45 & Male & 55 \\
\hline Case 3 & 47 & Male & 82 \\
\hline Case 4 & 67 & Male & 16 \\
\hline
\end{tabular}

HPV: human papilloma virus 


\section{Results}

The study included the tonsillar tissue samples from 206 cadavers. $166(80.6 \%)$ cadavers were male and $40(19.4 \%)$ were female. The mean age of the cadavers was $43.07 \pm 17.86$ (18-89). Figure 1 shows the number of cadavers for the age groups. Four (1.94\%) cases were detected to be HPV-positive (Table 1 ). All these cases were male, and their mean age was $44.75 \pm 19.25$ (20-67). Regarding the sub-typing of four HPV-positives cases, HPV-16 was detected in one case, and other three cases had HPV-82, HPV-55, and HPV-13, respectively. The prevalence of HPV-16, which is known to be the high-risk HPV, was $0.48 \%$.

\section{Discussion}

Viral etiology is thought to be responsible for $15 \%$ of all cases of cancer (12). HPV is one of the most common agents. After the recent documentation of the relationship between oropharyngeal cancers and HPV, the significance of HPV infection has remarkably increased. There are many studies in the literature concerning the prevalence of oropharyngeal HPV infection in many countries (Table 2). In this study, the prevalence of all subtypes of HPV was found $1.94 \%$. The prevalence of HPV-16, which is the most commonly detected subtype of high-risk HPV, was found $0.48 \%$. In the literature, the prevalence of all subtypes is reported to vary between $1.25 \%-20 \%$. The rates of high-risk HPV and HPV16 vary between $0-10.7 \%$ and $0-6.3 \%(13-22)$. The rate of oropharyngeal HPV infection in the current study is lower than those reported in previous studies. This result could be related to the sociocultural features of the studied population. To verify this fact, we need further studies which regard all the demographic features of the Turkish population.

Gillison et al. (20) reported that all oropharyngeal HPV infections and its HPV-16 subtype were detected three times and five times more, respectively, in males than in females. Rosen et al. (19) reported that these rates to be two times and four times higher, respectively. On the other hand, a study conducted with 500 Italian subjects ages 19 to 35 years didn't demonstrate any statistical significance between males and females (22). In our study, all subjects were male.

Previous studies reported that the prevalence of oropharyngeal HPV infection increases with the age. Among their male subjects aged from 18 to 74 years, Kreimer et al. (13) found that the prevalence of HPV was at its lowest level of $3.2 \%$ between the ages of 18-24 and at its highest level of $6.1 \%$ between the ages of 55-74 years. Similarly, in a study with 5,579 subjects, Gillison et al. (20) found a $6.9 \%$ prevalence of $\mathrm{HPV}$, with $11.2 \%$ and $11.4 \%$ in the subgroups of $55-59$ and 60-64 years of age, respectively. This increment could be related to many factors. Most commonly proposed factors are the increment of oral HPV incidence with age, persistent and reactivated oral HPV infections and the immunologic deficiencies in elderly population (20-23). In our study, the mean age of four HPV-positive cases was 45 years, and the one HPV16-positive case was at the age of 67.

In studies on oropharyngeal infections, the methods of sampling and the demographic features of the related population vary widely $(13,14)$. In the healthy population, the most commonly used methods for sampling are oral rinse and mouthwash. These methods provide a simple sampling of the oral cavity and the oropharynx. The main disadvantage of this technique is the incapability of detecting the primary location of the infection. Furthermore, HPV is mainly located deep in the crypts of the tonsillar tissue, and oral irrigation is usually insufficient for detecting the HPV DNA (18). Relying on the fact that tonsillar tissue is the most common localization of HPV-related oropharyngeal carcinoma, the research of its

Table 2. Prevalence of oropharyngeal HPV infection in different countries

\begin{tabular}{|c|c|c|c|c|c|c|c|}
\hline & Country & $\begin{array}{l}\text { Age } \\
\text { Groups }\end{array}$ & $\begin{array}{l}\text { Sampling } \\
\text { Method }\end{array}$ & $\begin{array}{l}\text { Number of } \\
\text { Cases }\end{array}$ & $\begin{array}{l}\text { Prevalence of } \\
\text { Overall HPV }\end{array}$ & $\begin{array}{c}\text { Prevalence of } \\
\text { High-Risk HPV }\end{array}$ & $\begin{array}{c}\text { Prevalence of } \\
\text { HPV-16 }\end{array}$ \\
\hline \multirow[t]{3}{*}{ Kreimer et al. (13) (2011) } & Brazil & 18-74 (Male) & Oral rinse & 475 & $2.1 \%$ & $1.3 \%$ & $0.6 \%$ \\
\hline & Mexico & 18-74 (Male) & Oral rinse & 591 & $5.9 \%$ & $1 \%$ & $0.5 \%$ \\
\hline & USA & 18-74 (Male) & Oral rinse & 614 & $\% 3.6$ & $\% 1.6$ & $\% 0.7$ \\
\hline Du et al. (14) (2012) & Sweden & $15-23$ & Oral rinse & 483 & $9.3 \%$ & $7.2 \%$ & $2.9 \%$ \\
\hline Rusan et al. (15) (2015) & Denmark & $8-30$ & Tonsillectomy & 80 & $1.25 \%$ & $0 \%$ & 0 \\
\hline Ernster et al. (16) (2009) & USA & $>21$ & Tonsillectomy & 226 & - & $0 \%$ & $0 \%$ \\
\hline Colon-López et al. (17) (2014) & Puerto Rico & $>16$ & Oral rinse & 205 & $20.0 \%$ & $10.7 \%$ & 2.4 \\
\hline \multirow[t]{2}{*}{ Chen et al. (18) (2005) } & \multirow[t]{2}{*}{ Finland } & $1.5-72$ & Tonsillectomy & 212 & - & $6.3 \%$ & 0.6 \\
\hline & & $2-74$ & Tonsillar swabbing & 189 & - & $0.6 \%$ & $0.6 \%$ \\
\hline Rosen et al. (19) (2016) & Peru & $10-85$ & Oral rinse & 1099 & $6.8 \%$ & $2 \%$ & 1.1 \\
\hline Gillison et al. (20) (2012) & USA & $14-69$ & Oral rinse & 5579 & 6.9 & 3.7 & 1 \\
\hline Lang Kuhs et al. (21) (2013) & Costa Rica & $22-29$ (Female) & Oral rinse & 2926 & $1.9 \%$ & $1.3 \%$ & $0.4 \%$ \\
\hline Lupato et al. (22) (2017) & Italy & 19-35 & Oral rinse & 500 & $4 \%$ & $2.2 \%$ & $1.6 \%$ \\
\hline
\end{tabular}


prevalence is commonly performed on tonsillectomy specimens. The main disadvantage of this method is the limitation of the subject group regarding the different indications of the operation such as recurrent tonsillitis, chronic tonsillitis, and tonsillar hypertrophy (11). We investigated the tonsillar tissue of cadavers that underwent a routine autopsy. Therefore, the main advantage of our study is its superiority in reflecting the normal population with a broader aspect of view.

The limitation of our study is the lack of information about the detailed demographic and behavioral features of the cadavers. Oral sex, increasing number of sexual partners and smoking are the main risk factors of oral HPV infection (20). Our study doesn't include adequate information about these factors.

\section{Conclusion}

The prevalence of tonsillar HPV infections in Istanbul, Turkey is $1.94 \%$, and the prevalence of HPV-16 infection is $0.48 \%$. Tonsillar HPV infection is more common in men than women.

Ethics Committee Approval: Ethics committee approval was received for this study from the Forensic Medicine Institution, Education and Scientific Research Commission (06.08.2015-21589509/704).

\section{Informed Consent: N/A}

Peer-review: Externally peer-reviewed.

Author Contributions: Concept - A.V.S., B.H., Ö.Y.; Design A.V.S., B.H., A.K., E.A.S.; Supervision - A.V.S., Ö.Y., K.M.; Data Collection and/or Processing - A.V.S., B.H., E.Ö.K., A.K., M.A.K., Y.E.D., K.M.; Analysis and/or Interpretation - A.V.S., E.A.S., A.K., M.A.K., Y.E.D.; Literature Search - A.V.S., B.H.; Writing - A.V.S., E.A.S, A.K., M.A.K.; Critical Reviews - A.V.S., Ö.Y., K.M.

Conflict of Interest: The authors have no conflicts of interest to declare.

Financial Disclosure: The authors declared that this study has received no financial support.

\section{References}

1. Hashibe M. Risk factors: Tobacco and alcohol. Olshan AF, editor. Epidemiology, pathogenesis, and prevention of head and neck cancer. New York: Springer; 2010. p. 65-85. [CrossRef]

2. Chaturvedi AK, Engels EA, Anderson WF, Gillison ML. Incidence trends for human papillomavirus-related and -unrelated oral squamous cell carcinomas in the United States. J Clin Oncol 2008; 26: 612-9. [CrossRef]

3. Chaturvedi AK, Engels EA, Pfieffer RM, Hernandez BY, Xiao W, Kim E, et al. Human papillomavirus and rising oropharyngeal cancer incidence in the United States. J Clin Oncol 2011; 29: 4294-301. [CrossRef]

4. Fakhry C, Gillison ML. Clinical implications of human papillomavirus in head and neck cancers. J Clin Oncol 2006; 24: 2606-11. [CrossRef]
5. D'Souza G, Kreimer AR, Viscidi R, Pawlita M, Fakhry C, Koch WM, et al. Case-control study of human papillomavirus and oropharyngeal cancer. N Engl J Med 2007; 356: 1944-56. [CrossRef]

6. Ernster JA, Sciotto CG, O'Brien MM, Finch JL, Robinson LJ, Willson T, et al. Rising incidence of oropharyngeal cancer and the role of oncogenic human papilloma virus. Laryngoscope 2007; 117: 2115-28. [CrossRef]

7. Tural D, Elicin O, Batur S, Arslan D, Oz B, Serdengecti S, et al. Increase in the rate of HPV positive oropharyngeal cancers during 1996-2011 in a case study in Turkey. Asian Pac J Cancer Prev 2013; 14: 6065-8. [CrossRef]

8. Haedicke J, Iftner T. Human papillomaviruses and cancer. Radiother Oncol 2013; 108: 397-402. [CrossRef]

9. Bosch FX, Broker TR, Forman D, Moscicki AB, Gillison ML, Doorbar J, et al. Comprehensive control of human papillomavirus infections and related diseases. Vaccine 2013; 31: 1-31. [CrossRef]

10. Beachler DC, Weber KM, Margolick JB, Strickler HD, Cranston RD, Burk RD, et al. Risk factors for oral HPV infection among a high prevalence population of HIV-positive and atrisk HIV-negative adults. Cancer Epidemiol Biomarkers Prev 2012; 21: 122-33. [CrossRef]

11. Rieth KKS, Gill SR, Lott-Limbach AA, Merkley MA, Botero N, Allen PD, et al. Prevalence of high-risk human papillomavirus in tonsil tissue in healthy adults and colocalization in biofilm of tonsillar crypts. JAMA Otolaryngol Head Neck Surg 2018; 144: 231-7. [CrossRef]

12. Parkin DM. The global health burden of infection-associated cancers in the year 2002. Int J Cancer 2006; 118: 3030-44. [CrossRef]

13. Kreimer AR, Villa A, Nyitray AG, Abrahamsen M, Papenfuss $\mathrm{M}$, Smith D, et al. The epidemiology of oral HPV infection among a multinational sample of healthy men. Cancer Epidemiol Biomarkers Prev 2011; 20: 172-82. [CrossRef]

14. Du J, Nordfors C, Ährlund-Richter A, Sobkowiak M, Romani$\tan$ M, Näsman A, et al. Prevalence of oral human papillomavirus infection among youth, Sweden. Emerg Infect Dis 2012; 18: 1468-71. [CrossRef]

15. Rusan M, Klug TE, Henriksen JJ, Bonde JH, Fuursted K, Ovesen T. Prevalence of tonsillar human papillomavirus infections in Denmark. Eur Arch Otorhinolaryngol 2015; 272: 2505-12. [CrossRef]

16. Ernster JA, Sciotto CG, O’Brien MM, Robinson LJ, Willson T. Prevalence of oncogenic human papillomavirus 16 and 18 in the palatine tonsils of the general adult population. Arch Otolaryngol Head Neck Surg 2009; 135: 554-7. [CrossRef]

17. Colon-López V, Quiñones-Avila V, Del Toro-Mejías LM, Reyes K, Rivera ME, Nieves K, et al. Oral HPV infection in a clinic-based sample of Hispanic men. BMC Oral Health 2014; 14: 7-16. [CrossRef]

18. Chen R, Sehr P, Waterboer T, Leivo I, Pawlita M, Vaheri A, et al. Presence of DNA of human papillomavirus 16 but no other types in tumor-free tonsillar tissue. J Clin Microbiol 2005; 43: 1408-10. [CrossRef]

19. Rosen BJ, Walter L, Gilman RH, Cabrerra L, Gravitt PE, Marks MA. Prevalence and correlates of oral human papillomavirus infection among healthy males and females in Lima, Peru. Sex Transm Infect 2016; 92: 149-54. [CrossRef]

20. Gillison ML, Broutian T, Pickard RK, Tong ZY, Xiao W, Kahle $\mathrm{L}$, et al. Prevalence of oral HPV infection in the United States, 2009-2010. JAMA 2012; 307: 693-703. [CrossRef] 
21. Lang Kuhs KA, Gonzalez P, Struijk L, Castro F, Hildesheim A, van Doorn LJ, et al. Prevalence of and risk factors for oral human papillomavirus among young women in Costa Rica. J Infect Dis 2013; 208: 1643-52. [CrossRef]

22. Lupato V, Holzinger D, Höfler D, Menegaldo A, Giorgi Rossi P, Del Mistro A, et al. Prevalence and determinants of oral human papillomavirus infection in 500 young adults from Italy. PLoS One 2017; 12: e0170091. [CrossRef]

23. García-Piñeres AJ, Hildesheim A, Herrero R, Trivett M, Williams $\mathrm{M}$, Atmetlla I, et al. Persistent human papillomavirus infection is associated with a generalized decrease in immune responsiveness in older women. Cancer Res 2006; 66: 11070-6. [CrossRef] 